\section{The Effect of National Business Systems on Social and Environmental Disclosure: A Comparison between Brazil and Canada}

\author{
Romulo Alves Soares ${ }^{1}$ \\ Mônica Cavalcanti Sá de Abreu ${ }^{1}$ \\ Silvia Maria Dias Pedro Rebouças ${ }^{1}$ \\ ${ }^{1}$ Federal University of Ceará, Fortaleza - Brazil
}

Pedro de Barros Leal Pinheiro Marino

${ }^{2}$ Business Department, Federal Institute of Brasilia, Brasilia - Brazil
Received on

09/25/2018

Approved on

05/01/2019

Responsible editor:

Prof. Dr. João Mauricio Gama

Boaventura

Evaluation process:

Double Blind Review

\begin{abstract}
Purpose - This paper evaluates the influence of the institutional environment on the extent of social and environmental disclosure of companies from institutionally distant countries.
\end{abstract}

Design/methodology/approach - We analyze basic materials, oil and gas, and public utility companies with shares traded on the Brazilian stock exchange (BM\&FBovespa) and Canadian stock exchange (Toronto Stock Exchange) from 2007 to 2015. Quantitative methods are adopted through descriptive statistics and panel data analysis. The econometric modeling considers environmental and social disclosure as dependent variables, independent variables that represent the political, financial, educational and labor systems, and firm size, ROA, and indebtedness as control variables.

Findings - In the case of the companies operating in Brazil, the extent of environmental and social disclosure is positively related to the political and labor systems, and negatively related to the financial system. In Canada, disclosure is negatively influenced by the financial system and the education system. The control variables, which represent characteristics of financial performance, were not significant.

Originality/value - The study shows that isomorphic forces operate in the institutional field and affect the adoption of socially responsible behavior. By basing the study on institutionally distinct countries, such as Brazil and Canada, it reinforces the influence of the national business system on the extent of disclosure of environmental and social practices.

Keywords - Institutional Theory, Disclosure, Sustainability Report, Corporate Social Responsibility, Stakeholder

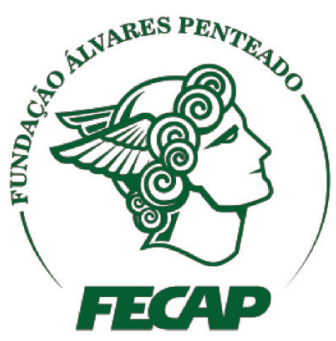

Review of Business Management

DOI:10.7819/rbgn.v22i1.4042 


\section{Introduction}

Institutional theory establishes that there are three sets of factors that shape organizational legitimacy: (1) characteristics of the institutional environment; (2) characteristics and actions of the organization; and (3) the process of legitimation by which the environment constructs its perceptions about the organization (Hybels, 1995). The process of legitimation involves continuous interaction with the environment (Baum \& Oliver, 1991). An essential part of the legitimation process is the disclosure of organizational practices to stakeholders. González-Benito and González-Benito (2006) argue that disclosure is important to improve the economic and social context in which the firm operates, and it builds communication channels with government, employees, clients, investors, and other stakeholders.

Companies are influenced by the institutional environment when structuring economic, environmental, and social policies and practices (Matten \& Moon, 2008). This idea is expanded by Whitley (2003), arguing that the national business system is related to the coherence of the institutional environment, and it helps to define the firm's strategic elements. The national business system involves five dimensions: "political," "financial," "education," "labor," and "culture," which are interconnected. Differences between national business systems reflect the degree of cooperation between consumers and suppliers and among competitors; the way in which the firm and controls are structured; the variety of resources and activities integrated through administrative hierarchies; the size of organizational integration; and the longterm interdependence between employees and employers (Brookes, Brewster, \& Wood, 2005).

Ioannou and Serafeim (2012) argue that the influence of the national business system on corporate social responsibility (CSR) practices is based on regulatory aspects, which end up homogenizing the way companies operate. Based on this perspective Jamali and Karam (2018) observe that there is a gap between national business systems in developed and developing countries, which contribute to the legitimacy of CSR practices. In developing countries, the philanthropic aspect is more important than legal and ethical dimensions, since there are institutional voids such as a lack of norms and regulations needed for full market operations (Schrammel, 2013).

Understanding how countries differ in their institutional dimensions (i.e. identifying the institutional distance between two countries) probably provides insight into the appropriate behavior of companies (Xu \& Shenkar, 2000). Kostova (1996) defined institutional distance as the difference or similarity between the regulatory, cognitive, and normative institutions of two countries. This distance affects the ability of the company to understand and correctly interpret local institutional requirements, as well as influencing its ability to identify the adjustment needed. According to Kogut (1991), organizational structures, policies, and practices tend to reflect the institutional environment in which they were developed.

Berry, Guillén, and Zhou (2010) argue that two countries may be distant from one another, not only for geographic reasons but also because of economic, social, cultural, and political issues. Youg and Rivers (2009) show that when there is a great divergence between the institutional environment of the country a company has its headquarters in, and the country the same company has a subsidiary in, the subsidiary rarely adopts the parent company's CSR practices, tending to adopt the local market's practices. Firms, therefore, tend to adopt the CSR practices observed in the local market.

When comparing firms that operate in institutionally distant environments, the organizational strategies observed can be explained based on differences in the political, financial, cultural, education, and labor systems, rather than by the firms' characteristics. This scenario 
can be exemplified in Brazil and Canada. From an economic point of view, the two countries are practically the same. In 2015, Brazil moved to 9th position and Canada to 10th among the world's largest economies. When considering human development, however, Canada is better ranked than Brazil. Between 2007 and 2014, Canada's Human Development Index (HDI) increased from 0.895 to 0.913 , while Brazil's increased from 0.721 to 0.755 (UNDP, 2017).

Brazil and Canada have distinct characteristics in their institutional structures. These differences significantly affect various aspects of the organizations in the countries (Delmas, 2002), especially the social and environmental practices they adopt (Matten \& Moon, 2008). For Thorne, Mahoney, Gregory, and Convery (2015), Canadian companies engage in social and environmental practices and strategic alliances in response to stakeholder pressures regarding CSR. In Brazil, as pointed out by Abreu, Cunha, and Barlow (2015), there is an institutional environment in which society, companies, and government do not act in a systematic way regarding social responsibility.

This study expands the debate on disclosure of CSR practices, examining the following research question: To what extent do the characteristics of the national business systems, in two institutionally distant countries, influence the disclosure of social and environmental practices? The relevance of this research lies in the need to understand the main factors that affect disclosure, especially the elements that are beyond the managers' direct control (Ioannou \& Serafeim, 2012).

Institutional diversity is regarded as the "distance" between the national business systems of Canada and Brazil since different institutional arrangements have distinct strengths and weaknesses for different types of economic activity. Countries differ in their economic, financial, and administrative practices, and such differences stem from demographic, geographic, cultural, and political factors and are capable of affecting managerial decision-making (Berry, Guillén, \& Zhou, 2010).

This study provides two contributions. First, it shows how isomorphic forces, operating in the institutional field, affect the adoption of socially responsible behavior, and it explores the effect of heterogeneity among countries on local isomorphism. Second, by basing the research on Brazil and Canada, the study contributes to the limited body of knowledge about the influence of national business systems on disclosure of CSR practices in institutionally distant countries (Tschopp, Wells, \& Barney, 2012; Orlitzk, Louche, Gond, \& Chapple, 2017).

The next section presents the hypotheses regarding the influence of the political, financial, education, and labor systems on the disclosure of CSR practices. The following section describes the methodology used to perform the econometric modeling using panel data based on the period from 2007 to 2015. Based on the data collected in the reports of firms listed on the BM\&FBovespa Brazilian stock exchange and the Toronto Stock Exchange (Canada), the sample contained 264 observations, of 127 of firms in Brazil and 137 firms in Canada. Finally, the article presents and discusses the results obtained, which show different isomorphic pressures influencing the disclosure of CSR practices.

\section{Influence of the national business system on the disclosure of social and environmental practices}

Global companies face market and institutional pressures to be socially responsible and disclose practices (Golob \& Bartlett, 2007). Abreu et al. (2015) reinforce the need to pay more attention to the relationship between the organizational field and institutional dynamics, which has an impact on different CSR approaches among developed and developing countries. In developing countries in general, national business systems have evolved in environments with high corruption levels, weak regulatory oversight and financial institutions, governance 
complications, and difficulties regarding citizens' voice and action. In this context, CSR is usually characterized as less formalized, more submerged, and more philanthropic (Visser, 2008).

Matten and Moon (2008) suggest a framework demonstrating how isomorphic institutional forces and specific national institutional structures act upon the firm and influence its explicit and implicit CSR practices. They explain that while the explicit and implicit forms of CSR result in similar practices, "explicit CSR" results from deliberate, voluntary, and often strategic corporate decisions. On the other hand, "implicit CSR" is a reflection of the obligations of the institutional environment of the company. Therefore, "explicit" social and environmental practices are spreading globally due to coercive, mimetic, and normative isomorphism.

Tang and Li (2009) argue that disclosure meets society's demand for accountability, reporting the social and environmental impact of the organization's economic activities. Disclosure exposes the firm's return for the economic gains obtained when using natural, material, or human resources in a given locality (Conceição et al., 2011).

\section{I The influence of the political system on the disclosure of social and environmental practices}

Regarding the influence of the political system, it is important to observe that the government is evaluated by principles, governance processes, and implementation of public policies (Bovaird \& Löffler, 2003). Whitley (1999) showed that the essential feature of any political system is the extent to which the state dominates the economy and shares risks so that businesses are dependent on state policies and actions. Ntim and Soobaroyen (2013) note that governments, as social institutions, have the coercive power of the state (for instance, through laws and monitoring) to regulate the behavior of companies and society.

Bovaird and Löffler (2003) emphasize that governments cannot be evaluated exclusively for the quality of their services, but also for the way they exercise their political, environmental, and social responsibilities. The government is therefore evaluated by the degree of implementation of the set of principles and processes of governance, as well as by the outcomes of public policies. Matten and Moon (2008) argue that the central feature that distinguishes the American and European political system is the state's engagement in economic and social activities such as education, health, and social security.

Lattermann, Kupke, and Schneider (2007) applied the governance environment approach to compare CSR disclosure between Chinese and Indian multinational companies and found that the governance environment affects the disclosure of CSR. The results found by $\mathrm{Li}$ et al. (2010) showed that the most important driving forces for the intensity of disclosure are factors related to the country's governance environment, followed by factors related to the sector and the company. Thus, when the country's political environment is favorable, companies are expected to be encouraged to show their social and environmental practices.

On the other hand, in high-corruption environments, Ioannou and Serafeim (2012) observed that firms are more likely to engage in unethical practices to reduce their costs and remain competitive (such as using child labor or increasing market share through bribery). It seems that when the government apparatus fails, due to a lack of infrastructure or corruption, economic forces operate without appropriate legal or moral controls (Scherer \& Palazzo, 2008).

Ali and Rizwan (2013) confirmed that government is a powerful stakeholder, forcing the disclosure of social and environmental practices in developing countries. Murillo-Luna et al. (2008) observed that the government's coercive influence, such as through binding guidelines or regulations, leads to the implementation of a corporate environmental policy. Dögl and Behnam (2015) demonstrated that regulatory influences are significant for the implementation 
of corporate environmental responsibility practices in developed countries, but not in emerging countries. Thus, it is possible to consider the following hypothesis for the political system:

$\mathbf{H}_{1}$ : The country's governance environment positively influences the disclosure of social and environmental practices.

\subsection{The influence of the financial system on the disclosure of social and environmental practices}

Institutional theory argues that firms adopt certain behaviors to gain access to investors' financial resources and support from strategic stakeholders (DiMaggio \& Powell, 1983). There is significant diversity in financing arrangements between different countries. According to Whitley (1999), the main characteristic of national financial systems is their dependence on the stock market (investors) or bank credit.

The stock market requires more disclosure than bank financing because shareholders are subject to more risk than the debt holder (Debreceny, Gray, \& Rahman, 2002). According to Ioannou and Serafeim (2012), in well-developed stock market-based financial systems, corporations strive to attract lower-cost investments.

Disclosure seems to provide investorrelevant information about company performance and decreases informational asymmetry (Dhaliwal, Li, Tsang, \& Yang, 2014). Haig and Hazelton (2004) point out that the financial returns from "socially responsible investment funds" pay better than traditional investments since these funds have a competitive advantage based on innovation, product differentiation, and the adoption of environmental and social practices.

Funding decisions in equity markets are usually based on short-term profitability. Within this system, investors focus on profit maximization and are less attracted to socially responsible investments. Ioannou and Serafeim (2015) clarify that the benefits of CSR, such as reputation building, usually occur in the long term.

However, Cheng, Ioannou, and Serafeim (2014) observe that the efficiency of the capital allocation process in the stock market requires an adequate disclosure mechanism. In this way, the more difficult it is to raise funds in a country's financial system, the greater the need for the participants in this system to use the information disclosed by the companies. Therefore, the hypothesis regarding the financial system is:

\section{$\mathbf{H}_{2}$ : The country's capital market negatively influences the disclosure of social and environmental practices.}

\subsection{The influence of the education and labor system on the disclosure of social and environmental practices}

Another institutional aspect that influences company behavior is the system related to the development and control of skills. According to Whitley (1999), this system is formed of the national education system, composed of institutions that develop and certify competencies. As for the labor system, it consists of institutions that control the terms on which the owners of the skills and competencies sell them in the labor market (Ioannou \& Serafeim, 2012).

Research shows that the practicing of CSR is related to managers' and investors' education levels (Huang, 2013; Cheah, Jamali, Johnson, $\&$ Sung, 2011). Investors with higher education levels tend to be more aware of the social and environmental impacts of business activities, and skeptical of the information contained in firms' reports. Muttakin, Khan, and Subramanian (2015) point out that in developing countries, often due to lack of experience and adequate academic training, managers do not see the importance of disclosure.

On the other hand, managers with international experience and qualifications are usually more prepared to meet the demands of stakeholders, carrying out outstanding work in 
the disclosure of the firm's practices, minimizing information asymmetry, and offering stakeholders access to relevant data (Muttakin, Khan, \& Subramanian, 2015). Therefore, the following hypothesis is proposed for the education system:

$\mathbf{H}_{3}$ : The quality of the education system positively influences the disclosure of social and environmental practices.

Another feature of the national business system involves labor relations, especially the employee-employer collaboration (Whitley, 1999). Several standards and methodologies used to measure disclosure of social and environmental practices address aspects related to well-being, education, training and development, profitsharing, health and safety at work, and prevention of child and forced labor (Orlitzky, Louche, Gond, \& Chapple, 2015). Disclosure is expanded to the extent that it meets the demands of particular groups of stakeholders, including employees (van Der Laan, 2009).

Reed (2002) states that the labor market distinguishes the economies of developed and developing countries. In developing countries the labor market is typically characterized by high levels of unemployment, the relative inability of trade unions to represent the interests of workers, no guarantee of a lasting permanence in employment, and a small margin for negotiating salaries.

On the other hand, Ioannou and Serafeim (2012) argue that in countries where trade unions are more prominent, firms will perform better in CSR practices, as powerful unions may push for employees' benefits in the form of provisions regarding health and safety, as well as progressive labor policies, and more amenities in the workplace. Thus, the hypothesis proposed for the labor system is:

$\mathbf{H}_{4}$ : Collaboration in labor relations positively influences the disclosure of social and environmental practices.

\section{METHODOLOGY}

\section{I Sampling procedure}

The sample of this research is formed of companies in Brazil and Canada, included in the Forbes list "Global 2000 - The World's Largest Public Companies," published in 2008 (using data from 2007). The selected companies were publicly traded firms listed in the B3 Brazilian stock exchange and the Toronto Stock Exchange, operating in three sectors: basic materials, oil and gas, and utilities. The sample was formed of 33 companies. The study collected the companies' sustainability reports available in the period from 2007 to 2015, from the firms' institutional websites and the Global Reporting Initiative (GRI) database. In total, the research included 259 observations, 127 of companies in Brazil and 132 of companies in Canada. Table 1 shows the sample composition. 
Table 1

Sample composition per country and sector.

\begin{tabular}{|c|c|c|c|c|c|c|c|c|}
\hline \multirow{2}{*}{ Country } & \multicolumn{3}{|c|}{ Number of firms per sector } & \multirow{2}{*}{ Total } & \multicolumn{3}{|c|}{ Number of observations per sector } & \multirow{2}{*}{ Total } \\
\hline & Oil and gas & Basic materials & Utilities & & Oil and gas & Basic materials & Utilities & \\
\hline \multirow{2}{*}{ Brazil } & 2 & 7 & 7 & 16 & 17 & 50 & 60 & 127 \\
\hline & $12.4 \%$ & $43.8 \%$ & $43.8 \%$ & $100 \%$ & $13.4 \%$ & $39.4 \%$ & $47.2 \%$ & $100 \%$ \\
\hline \multirow{2}{*}{ Canada } & 7 & 8 & 2 & 17 & 53 & 64 & 15 & 132 \\
\hline & $41.2 \%$ & $47.1 \%$ & $11.7 \%$ & $100 \%$ & $40.2 \%$ & $48.5 \%$ & $11.4 \%$ & $100 \%$ \\
\hline \multirow{2}{*}{ Total } & 9 & 15 & 9 & 33 & 70 & 114 & 75 & 259 \\
\hline & $27.3 \%$ & $45.4 \%$ & $27.3 \%$ & $100 \%$ & $27.0 \%$ & $44.0 \%$ & $29.0 \%$ & $100 \%$ \\
\hline
\end{tabular}

Source: Elaborated by the authors

In the sample of firms in Brazil, there is a predominance of companies in the basic materials and utilities sectors. In the sample of firms in Canada, there is a predominance of firms listed in the basic materials sector followed by oil and gas and utilities. In 2017, mineral and metal exploration (basic materials sector) accounted for $27 \%$ of Brazilian exports and $31 \%$ of Canadian exports, according to data from The Observatory of Economic Complexity. There are few companies in the oil and gas sector in Brazil, which characterizes an oligopolized sector, with large companies that dominate the entire production chain.

\subsection{Dependent, independent, and control variable definitions}

The GRI performance indicators were used to evaluate the extent of the disclosure of social and environmental practices. The indicators were organized into the environmental and social dimensions, following the methodology proposed by Fischer and Sawczyn (2013). The environmental dimension has nine categories, and the social dimension presents 14 categories. These two dimensions were merged, forming the variable "social and environmental disclosure" (SED).

Following Fischer and Sawczyn (2013), each category was scored from 0 to 6 , considering:
0 when no information is disclosed; 1 when performance information is presented in absolute or relative terms. An additional point is added when, in addition to the information in absolute or relative terms, there is information: in comparison with similar/rival firms in the sector; in comparison with previous periods; in comparison with targets; in a normalized way, or in disaggregated form. The SED variable was considered in percentage, so a firm with indicators with a score of 6 will present, for analysis, 100\% disclosure. The characteristics evaluated for each indicator are presented in Table 2.

Table 2

\section{Characteristics assessed using social and environmental indicators}

\begin{tabular}{lc}
\hline Characteristics & Values \\
\hline Absent indicator & 0 \\
\hline $\begin{array}{l}\text { Absolute or relative performance information is } \\
\text { presented }\end{array}$ & 1 \\
\hline $\begin{array}{l}\text { Information is presented and compared with other } \\
\text { frrms in the sector }\end{array}$ & +1 \\
\hline $\begin{array}{l}\text { Information is presented and compared with } \\
\text { previous periods }\end{array}$ & +1 \\
\hline $\begin{array}{l}\text { Information is presented and compared with } \\
\text { targets }\end{array}$ & +1 \\
\hline $\begin{array}{l}\text { Information is presented also in normalized form } \\
\text { Information is presented in disaggregated form }\end{array}$ & +1 \\
\hline Maximum points per indicator & 6 \\
\hline $\begin{array}{l}\text { Source: Elaborated by the authors based on Fischer and } \\
\text { Sawczyn (2013). }\end{array}$
\end{tabular}


The independent variables are related to the institutional structures that make up the two countries' national business systems. An indicator was chosen as a proxy to represent each pillar of the system. The indicators were selected from the databases of two international bodies: The World Bank and the World Economic Forum. Table 3 presents a synthesis of the independent variables related to the hypotheses, research description, and the data source. It is observed that the selected indicators have different scales. Therefore, for a better comparison between them, the indicators were standardized on the same scale, with values in the range of 0 for the lowest value and 1 for the highest value observed.

Table 3

\section{Independent variables and sources}

\begin{tabular}{|c|c|c|c|c|}
\hline Variables & Indicator & Description & Operationalization & Data source \\
\hline $\begin{array}{l}\text { Political } \\
\text { system } \\
\text { (POL) }\end{array}$ & $\begin{array}{c}\text { Worldwide } \\
\text { Governance Indicators }\end{array}$ & $\begin{array}{l}\text { Set of indicators used to assess the } \\
\text { quality of public governance in the } \\
\text { country }\end{array}$ & $\begin{array}{l}\text { WGI indicators involve six dimensions: } \\
\text { voice and accountability, political } \\
\text { stability and absence of violence, } \\
\text { government effectiveness, regulatory } \\
\text { quality, the rule of law, and control of } \\
\text { corruption. The indicators are measured } \\
\text { on a scale from }-2.5 \text { to } 2.5\end{array}$ & The World Bank \\
\hline $\begin{array}{l}\text { Financial } \\
\text { system } \\
(\text { FIN) }\end{array}$ & $\begin{array}{c}\text { Financing through the } \\
\text { local equity market }\end{array}$ & $\begin{array}{c}\text { Related to the company's capacity } \\
\text { to fund its activities through the } \\
\text { equity market }\end{array}$ & $\begin{array}{l}\text { Executives' opinions on how easy } \\
\text { it is for private businesses to obtain } \\
\text { equity funding by trading stocks and } \\
\text { securities, using a scale from } 1 \text { to } 7\end{array}$ & \multirow{3}{*}{$\begin{array}{l}\text { World Economic } \\
\text { Forum's } \\
\text { (WEF) Global } \\
\text { Competitiveness } \\
\text { Index (GCI) }\end{array}$} \\
\hline $\begin{array}{l}\text { Education } \\
\text { system } \\
\text { (EDU) }\end{array}$ & $\begin{array}{l}\text { Quality of the } \\
\text { education system }\end{array}$ & $\begin{array}{l}\text { Related to the quality of the } \\
\text { education system based on four } \\
\text { elements of the teaching structure }\end{array}$ & $\begin{array}{l}\text { Executives' opinions on how the } \\
\text { country's education system responds to } \\
\text { the need for a competitive economy, } \\
\text { using a scale from } 1 \text { to } 7\end{array}$ & \\
\hline $\begin{array}{l}\text { Labor system } \\
\text { (LAB) }\end{array}$ & $\begin{array}{l}\text { Cooperation in labor- } \\
\text { employer relations }\end{array}$ & $\begin{array}{l}\text { Related to cooperation in the } \\
\text { worker-employer relationship }\end{array}$ & $\begin{array}{l}\text { Executives' opinions on the working } \\
\text { conditions, using a scale from } 1 \text { to } 7\end{array}$ & \\
\hline
\end{tabular}

Source: Based on field research

Also, three control variables related to the firms' financial characteristics were selected: size, leverage ratio, and profitability. This inclusion is based on the idea proposed by Roberts (1992), that a firm is more likely to adopt CSR practices depending on its financial circumstances. Size was measured using the natural logarithm of total assets.

It should be noted that for the Canadian firms, the asset value was converted from Canadian dollars into Brazilian reais, considering the exchange rate on December 31 of the year which the information refers to. The leverage ratio was measured based on the ratio between the debt capital (current liabilities + non-current liabilities) and total assets. Profitability was measured based on the return on assets (ROA), which divides earnings before interest and taxes by total assets.

\subsection{Econometric model}

For the test of the hypotheses $\left(\mathrm{H}_{1}, \mathrm{H}_{2}, \mathrm{H}_{3}\right.$, and $\mathrm{H}_{4}$ ), statistical techniques were used for panel data analysis. The panel data analysis method consisted of a combination of a cross-sectional and longitudinal section with two dimensions: time and space (Sonaglio, Zamberlan, Lime, \& Fields, 2010). The model used to test the research hypotheses was:

$$
\begin{gathered}
S E D_{i t}= \\
\beta_{0 i}+\beta_{1} P O L_{t}+\beta_{2} F_{I N}+\beta_{3} E D U_{t}+\beta_{4} L A B_{t}+\beta_{5} S I Z E_{i t}+\beta_{6} R O A_{i t}+\beta_{7} L E V E R A G E_{i t}+\mu_{i t} .
\end{gathered}
$$


Where SED is the indicator of CSR disclosure of company $i$ in year $t$; POL is the quality indicator of the political system of country $p$ in year $t$; FIN is the efficiency indicator of the financial system; EDU is the quality indicator of the education system; LAB is the indicator of collaboration in the work system; SIZE is the natural logarithm of the total assets of firm $i$ in year $t$; ROA represents the return on assets of firm $i$ in year $t$; and LEVERAGE represents the leverage ratio of firm $i$ in year $t$.

As the objective of the research was to observe the institutional distance between Brazil and Canada, separate regressions were carried out for the two countries. In both regressions, the Hausman test, F-test, and Breusch-Pagan test were performed to determine the best specification among the panel data models available (fixed effects, random effects, and pooling). The model presented in the results was the most adequate according to the tests performed. The study adopted the $\mathrm{R}$ software version 3.4.4 to carry out the tests and regressions.

\section{Results}

\section{I Descriptive analysis}

Table 4 presents the descriptive analysis of the independent variables related to institutional structures that form the national business systems of Brazil and Canada. In general, the two countries are statistically different in all aspects of their national business systems and in any time series (from 2007 to 2015). Also, the Canadian systems are more efficient than the Brazilian ones. The standardized scores for Canada show indicators that are, on average, 1.92, 1.66, 1.21, and 1.22 times higher than Brazil's, for the political, education, financial, and labor systems, respectively.

The results allow the analysis of how the systems behave over the years in both countries. In Brazil, the lowest values for the four systems are observed in 2015. In Canada, the lowest values are distributed in different years, with the lowest values for the political and labor systems observed in the first years analyzed (2007 and 2008, respectively) and those for the financial and education systems occurring at the end of the period (2013 and 2015, respectively). In addition, the percentage change between the highest and lowest value observed in each of the two countries shows a more homogeneous behavior for Canada, where the variations range between $1.6 \%$ (political system) and $14.8 \%$ (financial system). In Brazil, these variations are between $10.7 \%$ (political system) and $28.6 \%$ (financial system).

Table 4

Descriptive statistics of the national business system variables in the period from 2007 to 2015

\begin{tabular}{|c|c|c|c|c|c|c|c|c|c|c|c|}
\hline System & Country & 2007 & 2008 & 2009 & 2010 & 2011 & 2012 & 2013 & 2014 & 2015 & $\begin{array}{c}\text { Wilcoxon } \\
\text { test }\end{array}$ \\
\hline \multirow{2}{*}{ Political } & Brazil & 0.477 & 0.494 & 0.511 & 0.522 & 0.518 & 0.510 & 0.495 & 0.488 & 0.466 & \multirow{2}{*}{$* * *$} \\
\hline & Canada & 0.817 & 0.822 & 0.829 & 0.822 & 0.823 & 0.824 & 0.822 & 0.830 & 0.828 & \\
\hline \multirow{2}{*}{ Financial } & Brazil & 0.683 & 0.662 & 0.606 & 0.560 & 0.605 & 0.580 & 0.550 & 0.520 & 0.488 & \multirow{2}{*}{$* * *$} \\
\hline & Canada & 0.784 & 0.729 & 0.670 & 0.673 & 0.712 & 0.695 & 0.668 & 0.698 & 0.733 & \\
\hline \multirow{2}{*}{ Education } & Brazil & 0.358 & 0.386 & 0.430 & 0.446 & 0.429 & 0.424 & 0.426 & 0.389 & 0.349 & \multirow{2}{*}{$* * *$} \\
\hline & Canada & 0.755 & 0.798 & 0.819 & 0.808 & 0.775 & 0.772 & 0.750 & 0.749 & 0.729 & \\
\hline \multirow{2}{*}{ Labor } & Brazil & 0.596 & 0.618 & 0.601 & 0.583 & 0.597 & 0.608 & 0.591 & 0.534 & 0.510 & \multirow{2}{*}{$* * *$} \\
\hline & Canada & 0.690 & 0.696 & 0.703 & 0.713 & 0.723 & 0.721 & 0.704 & 0.708 & 0.726 & \\
\hline
\end{tabular}

Note: ${ }^{* * *}$ indicates that the difference between the countries is significant at $1 \%$. 
Table 5 shows the average disclosure of environmental practices of the firms in Brazil and Canada, from 2007 to 2015. The results show that the average disclosure of the firms in Brazil is higher than for the firms in Canada, reporting the significant impacts of activities, products, and services on the biodiversity of protected areas and areas with a high biodiversity index outside protected areas. Also, the firms in Brazil put more emphasis on the percentage of recovery of their product packaging, the percentage of recycled materials, and direct emissions of greenhouse gases.
The firms in Canada placed greater emphasis on the environmental aspects related to emissions that cause acid rain and indirect emissions of greenhouse gases. Environmental aspects related to production costs, such as consumption of materials, water, and energy; generation of waste; financial implications related to climate change; and the location and area of land with a high biodiversity index, do not present significant differences between the firms of the two countries.

Table 5

\section{Comparison of means of environmental indicators disclosed by the firms in Brazil and Canada}

\begin{tabular}{|c|c|c|c|c|c|}
\hline \multirow{2}{*}{ Indicators } & \multicolumn{2}{|c|}{ Brazil } & \multicolumn{2}{|c|}{ Canada } & \multirow{2}{*}{ T test } \\
\hline & $\mu$ & $\sigma$ & $\mu$ & $\sigma$ & \\
\hline $\begin{array}{l}\text { Description of the significant impacts on the biodiversity of any activities, products, and } \\
\text { services in protected areas and those with a high biodiversity index outside protected areas }\end{array}$ & 1.31 & 0.90 & 0.99 & 0.94 & 0.006 \\
\hline Percentage of recycled materials used & 0.96 & 1.07 & 0.53 & 0.81 & 0.000 \\
\hline Total direct emissions of greenhouse gases, by weight & 0.94 & 0.89 & 0.77 & 0.77 & 0.095 \\
\hline Percentage of packaging recovered in relation to the total number of products sold & 0.26 & 0.70 & 0.12 & 0.34 & 0.035 \\
\hline Relevant indirect emissions of greenhouses gases, by weight & 1.97 & 1.30 & 2.52 & 1.28 & 0.001 \\
\hline Total discharge of water, by quality and destination & 1.43 & 1.58 & 1.82 & 1.41 & 0.035 \\
\hline $\mathrm{NO}_{\mathrm{x}}, \mathrm{SO}_{\mathrm{x}}$, and other significant atmospheric emissions, by type and weight & 0.46 & 0.88 & 0.98 & 1.13 & 0.000 \\
\hline Total water used according to its source & 1.86 & 1.47 & 1.77 & 1.36 & 0.628 \\
\hline Direct consumption of energy according to the primary source & 1.83 & 1.09 & 1.85 & 1.36 & 0.937 \\
\hline Total weight of waste, by type and method of disposal & 1.64 & 1.40 & 1.76 & 1.25 & 0.456 \\
\hline $\begin{array}{l}\text { Location and size of the properties owned, leased, or administered within protected areas or } \\
\text { adjacent to them, and areas with a high biodiversity index outside protected areas }\end{array}$ & 1.36 & 1.45 & 1.39 & 1.16 & 0.878 \\
\hline Indirect consumption of energy according to the primary source & 1.35 & 1.42 & 1.42 & 1.29 & 0.645 \\
\hline Emission of substances that destroy the ozone layer, by weight & 1.23 & 1.24 & 1.04 & 1.19 & 0.218 \\
\hline $\begin{array}{l}\text { Initiatives to mitigate the environmental impacts of products and services and the extent of } \\
\text { the reduction of these impacts }\end{array}$ & 1.20 & 0.92 & 1.29 & 0.85 & 0.424 \\
\hline Financial implications and other risks and opportunities due to climate change & 0.99 & 0.81 & 0.93 & 0.82 & 0.517 \\
\hline
\end{tabular}

Source: Elaborated using research data

Table 6 shows the average disclosure of social practices of the firms in Brazil and Canada, in the same period. The results show that, in the vast majority of social issues, the average disclosure of the firms in Brazil is significantly different and greater than that of the firms in Canada. In Brazil, despite presenting a higher level of disclosure, the firms' practices reflect weaknesses in the country's regulatory and normative institutions. The emphasis is on showing practices related to fighting employee discrimination, child labor, forced labor, corruption, and wage differences between men and women. Also, the firms emphasize training, minority support programs, information on products and services, and impacts on workers' health and safety. 
As for the firms in Canada, the disclosures on the rate of injuries, occupational diseases, lost days, absenteeism, and work-related deaths stand out, which present a higher value and are more significant in relation to the firms in
Brazil. Practices regarding production costs, such as turnover rate, impacts on infrastructure investments, benefit plans, and cost policies with suppliers do not present significant differences between the firms in the two countries.

Table 6

\section{Comparison of means of social indicators disclosed by firms in Brazil and Canada}

\begin{tabular}{|c|c|c|c|c|c|}
\hline \multirow{2}{*}{ Indicators } & \multicolumn{2}{|c|}{ Brazil } & \multicolumn{2}{|c|}{ Canada } & \multirow{2}{*}{ T test } \\
\hline & $\mu$ & $\sigma$ & $\mu$ & $\sigma$ & \\
\hline Total employees, by type of employment, labor contract, and region & 1.89 & 1.20 & 1.61 & 1.04 & 0.046 \\
\hline Average hours of training per year, per employee, defined by their job category & 1.65 & 1.03 & 0.58 & 0.91 & 0.000 \\
\hline $\begin{array}{l}\text { Composition of the groups responsible for corporate governance and the listing of employees by } \\
\text { category, according to gender, age, minorities, and other indicators of diversity }\end{array}$ & 1.46 & 1.21 & 0.93 & 1.18 & 0.000 \\
\hline The proportion of base salary between men and women per job category & 1.06 & 1.15 & 0.48 & 0.91 & 0.000 \\
\hline $\begin{array}{l}\text { Operations identified as a significant risk in terms of involving child labor and the measures taken } \\
\text { to contribute to the abolition of child labor }\end{array}$ & 0.93 & 0.92 & 0.27 & 0.45 & 0.000 \\
\hline $\begin{array}{l}\text { Operations identified as a significant risk in terms of involving forced labor or any kind of slavery } \\
\text { and the measures taken for the eradication of this type of work }\end{array}$ & 0.92 & 0.91 & 0.27 & 0.45 & 0.000 \\
\hline Measures taken in response to cases of corruption & 0.85 & 0.91 & 0.67 & 0.81 & 0.093 \\
\hline Total number of cases of discrimination and the measures taken & 0.72 & 0.75 & 0.46 & 0.65 & 0.002 \\
\hline $\begin{array}{l}\text { Type of information about products and services required by labeling procedures, and the } \\
\text { percentage of products and services subject to these requirements }\end{array}$ & 0.42 & 0.53 & 0.23 & 0.53 & 0.004 \\
\hline $\begin{array}{l}\text { Phases of the life cycle of products and services in which the impacts on health and safety are } \\
\text { evaluated for improvements to be made, and the percentage of products and services subject to } \\
\text { these procedures. }\end{array}$ & 0.34 & 0.51 & 0.18 & 0.41 & 0.006 \\
\hline $\begin{array}{l}\text { Rate of injuries, occupational illnesses, number of days lost, absenteeism, and work-related deaths, } \\
\text { per region }\end{array}$ & 1.76 & 1.28 & 2.18 & 1.06 & 0.005 \\
\hline Total number and turnover rate of employees, by age, gender, and region & 1.68 & 1.21 & 1.56 & 1.08 & 0.415 \\
\hline $\begin{array}{l}\text { Development and impact of investment in infrastructure and services offered particularly for the } \\
\text { benefit of the public, by means of commercial involvement, in cash or pro bono activities }\end{array}$ & 1.49 & 1.12 & 1.64 & 1.22 & 0.286 \\
\hline Coverage of the obligations related to the defined benefit pension plan that the organization offers & 1.06 & 0.90 & 1.02 & 1.16 & 0.796 \\
\hline Policies, practices, and proportions of spending with local suppliers by important operating units & 1.03 & 1.05 & 1.19 & 1.20 & 0.254 \\
\hline
\end{tabular}

Source: Elaborated using the research data.

The firms in Brazil present greater disclosure involving a more comprehensive set of environmental and social practices. Notwithstanding, Brazil has a weaker institutional environment in all aspects (see Table 4). Thus, what is observed in the firms in the country is the disclosure of "explicit" CSR practices. On the other hand, the firms in Canada, since they operate in an environment where there are stronger institutions, end up adopting "implicit" CSR practices.

\subsection{Econometric analysis}

Regarding the regression analysis, the random effects panel data model was used for the two countries, since this model was proven to be superior to the other two possibilities (fixed effects and pooling). For the model with firms in Brazil, the Hausman test presented a statistical significance of 0.944 , while the $F$ and Breusch-Pagan tests for the panel effects presented a statistical significance of 0.000 . For 
the model with firms in Canada, the Hausman test presented a statistical significance of 0.999, and the F and Breusch-Pagan tests for panel effects also presented a statistical significance of 0.000 (Table 7).

Table 7

Results of the panel models for firms in Brazil and Canada

\begin{tabular}{|c|c|c|c|c|}
\hline \multirow{2}{*}{ Variables } & \multicolumn{2}{|c|}{ Firms in Brazil } & \multicolumn{2}{|c|}{ Firms in Canada } \\
\hline & Coefficient & P-value & Coefficient & P-value \\
\hline Intercept & -0.536 & 0.205 & 0.931 & 0.489 \\
\hline POL & 2.111 & $0.072^{*}$ & -0.383 & 0.799 \\
\hline FIN & -0.793 & $0.018^{* *}$ & -0.597 & $0.002^{* * *}$ \\
\hline EDU & -1.158 & 0.160 & -0.779 & $0.000^{* * *}$ \\
\hline $\mathrm{LAB}$ & 1.050 & $0.071^{*}$ & 0.668 & 0.162 \\
\hline Size & 0.003 & 0.870 & 0.005 & 0.145 \\
\hline ROA & 0.072 & 0.507 & 0.060 & 0.440 \\
\hline Leverage ratio & -0.082 & 0.301 & -0.001 & 0.989 \\
\hline Wald $\chi^{2}$ & \multicolumn{2}{|c|}{$19.01(0.000)$} & \multicolumn{2}{|c|}{$29.28(0.000)$} \\
\hline $\mathrm{R}^{2}$ & \multicolumn{2}{|c|}{0.107} & \multicolumn{2}{|c|}{0.056} \\
\hline Hausman test & \multicolumn{2}{|c|}{$2.26(0.944)$} & \multicolumn{2}{|c|}{$0.52(0.999)$} \\
\hline Effect & \multicolumn{2}{|c|}{ Random } & \multicolumn{2}{|c|}{ Random } \\
\hline
\end{tabular}

Note: ${ }^{*}<10 \%,{ }^{* *}<5 \%,{ }^{* * *}<1 \%$.

Source: Based on the research data

As observed in Table 7, the random effects model for the firms in Brazil has an $\mathrm{R}^{2}$ of 0.107 and a $\mathrm{p}$-value for the F-test with a significance level of less than 0.01 . It was identified that the political and labor systems have a positive and significant effect at the 0.10 level on social and environmental disclosure, and the financial system has a negative and significant effect at the 0.05 level. For the firms in Canada, the model has an $\mathrm{R}^{2}$ of 0.056 and an F-test with statistical significance lower than 0.01 . The same negative effect, significant at the 0.01 level, is observed in the social and environmental disclosure for the financial system. It is also observed that the education system has a negative and significant effect. For both countries, the control variables do not exert a significant effect on SED.
Table 8 shows the relationship between the results of the panel data analysis and the assumptions made in the hypotheses. The increase in social and environmental disclosure practices is positively related to the political system for the firms in Brazil, as assumed in $\mathrm{H}_{1}$. However, this hypothesis was not supported when analyzing the firms in Canada. The results for the tests for $\mathrm{H}_{2}$ related to the financial system in both countries support the hypothesis since the influence observed was negative. However, the value of the coefficient for the companies in Brazil indicates a more significant influence than that observed for the firms in Canada. 
Table 8

Synthesis of the results of the hypotheses tests

\begin{tabular}{|c|c|c|c|c|c|}
\hline \multicolumn{2}{|c|}{ Hypothesis } & \multirow{3}{*}{$\begin{array}{c}\text { Relationship } \\
+\end{array}$} & \multirow{3}{*}{$\begin{array}{c}\text { Result } \\
\text { Positive effect of public governance on disclosure }\end{array}$} & \multirow{2}{*}{$\begin{array}{c}\text { Country } \\
\text { Brazil } \\
\end{array}$} & \multirow{2}{*}{$\begin{array}{c}\text { Supported } \\
\text { YES } \\
\end{array}$} \\
\hline & & & & & \\
\hline $\mathrm{H}_{1}$ & POL $\rightarrow$ SED & & & Canada & $\mathrm{NO}$ \\
\hline \multirow{2}{*}{$\mathrm{H}_{2}$} & \multirow{2}{*}{$\mathrm{FIN} \rightarrow \mathrm{SED}$} & \multirow{2}{*}{-} & \multirow{2}{*}{$\begin{array}{l}\text { Negative effect of the ease of raising funds on } \\
\text { disclosure }\end{array}$} & Brazil & YES \\
\hline & & & & Canada & YES \\
\hline \multirow{2}{*}{$\mathrm{H}_{3}$} & \multirow{2}{*}{$\mathrm{EDU} \rightarrow \mathrm{SED}$} & \multirow{2}{*}{+} & \multirow{2}{*}{$\begin{array}{l}\text { Negative effect of the quality of education on } \\
\text { disclosure }\end{array}$} & Brazil & $\mathrm{NO}$ \\
\hline & & & & Canada & $\mathrm{NO}$ \\
\hline \multirow{2}{*}{$\mathrm{H}_{4}$} & \multirow{2}{*}{$\mathrm{LAB} \rightarrow \mathrm{SED}$} & \multirow{2}{*}{+} & \multirow{2}{*}{$\begin{array}{l}\text { Positive effect of the employer-employee } \\
\text { collaboration on disclosure }\end{array}$} & Brazil & YES \\
\hline & & & & Canada & $\mathrm{NO}$ \\
\hline
\end{tabular}

Source: Based on the results presented in Table 7

Hypothesis $\mathrm{H}_{3}$ was rejected for companies in Brazil and Canada. In the case of Canada, the education system is negatively related to social and environmental disclosure, contrary to the hypothesis' proposition. Finally, hypothesis $\mathrm{H}_{4}$ indicates a positive effect of the employer and employee collaboration on disclosure, but the results only supported this assumption for the companies in Brazil.

\section{Discussion}

The research confirms the influence of the national business system on the level of disclosure of social and environmental practices in institutionally distant countries. The results indicate that in Canada there is a predominance of coercive and normative isomorphism. Canadian companies adopt behaviors that meet the legal requirements and, therefore, do not need to report social and environmental practices to their stakeholders. In the case of Brazil, in the absence of coercive pressures, normative and mimetic isomorphism seems to predominate.

As for the political system, Canada is one of the top 15 countries regarding the quality of public governance, whereas Brazil is below the 100 best countries in this aspect. According to the World Bank (2017), in terms of public governance, for the six WGI dimensions Canada is ranked better than $90 \%$ of the countries analyzed, while Brazil is in the bottom $50 \%$ of the researched countries in all six dimensions. As for the financial system, in 2015, in a ranking of 138 countries, Canada was ranked in $14^{\text {th }}$ place for funding through the capital market, while Brazil ranked $83^{\text {rd }}$. Canada also ranked $15^{\text {th }}$ in executives' perceptions of how much the education system meets the needs of a competitive economy, while Brazil ranked $128^{\text {th }}$. Finally, regarding the labor system, Canada ranked $20^{\text {th }}$ and Brazil ranked $118^{\text {th }}$ in terms of the quality of employee and employer collaboration (World Economic Forum, 2017).

When analyzing the results for each of the hypotheses, it is observed that the weak public governance in Brazil positively influences the disclosure of social and environmental practices. Similar findings were reported by Young and Marais (2012), who point out the effect of the governance of French and Australian firms on the nature of CSR disclosure. Lattermann, Kupke, and Schneider (2007) also find that the Chinese and Indian governance environment affects CSR disclosure. Li et al. (2010) show that, in BRIC countries, factors related to the countries' governance environment, followed by sector and company-related factors, are the most important driving forces for the intensity of CSR disclosure.

For companies in Canada, the political system does not have a significant effect on CSR 
disclosure. One possible explanation is related to the behavior of companies operating in countries with different coercive pressures and relates to the framework proposed by Matten and Moon (2008). In countries such as Canada, companies develop "implicit" CSR. On the other hand, in Brazil, companies adopt "explicit" CSR. In this sense, Damiano-Teixeira and Pompermayer (2007) reinforce the idea that companies in Brazil are becoming more active in dealing with social and environmental issues to move away from the image of corruption and the accumulation of wealth.

Regarding the financial system, there is an evident influence of regulatory pressures in both countries. The research revealed a negative relationship between how easy it is for firms to raise money in the capital market and the level of disclosure of social and environmental practices. This result indicates that the easier it is for companies to obtain funding in the stock market, the less likely it is that they will need to present themselves as socially responsible and, therefore, low-risk firms.

Using a sample of 11,672 observations from 53 countries between 2003 and 2010, El Ghoul, Guedhami, and Kim (2017) confirm that CSR practices help access better funding conditions. Weaker capital markets present higher transaction costs, and CSR practices can mitigate such costs by reducing informational asymmetry and agency costs.

The result for the influence of the quality of the education system on the extent of disclosure was statistically significant for Canada, although the relationship found was contrary to hypothesis $\mathrm{H}_{3}$. In countries where the education system is centralized by the government, firms develop more "implicit" CSR, which leads to less disclosure. Studies carried out by Ioannou and Serafeim (2012), with a sample of 180 American companies, between 1992 and 2010, point to a negative relationship between the quality of the education system and the extent of disclosure of social and environmental practices.
If skilled human capital is plentiful in the country, companies do not need to "compete" for talent with more disclosure.

The research shows that only the firms in Brazil present a significant influence of the labor system on the disclosure of CSR practices. Other studies that analyze the role of the labor system also point to a positive relationship, due to the importance of employees as one of the company's main stakeholders (Ioannou \& Serafim, 2012; Preuss, Barkemeyer, \& Glavas, 2016). Chih et al. (2010) find a positive relationship between disclosure and the quality of the employeeemployer relationship for a sample of 520 financial firms from 34 countries, and confirm that employees form a group of stakeholders capable of demanding better social practices through cognitive pressures.

\section{Conclusion}

The study shows that isomorphic forces operate in the institutional field and affect the adoption of socially responsible behavior. The use of indicators for the institutional structures that shape national business systems allows for new insights into firms' socially responsible behavior. In the managerial field, the results of the study indicate that institutionally distant countries are subject to the influence of different coercive, normative, and cognitive pressures when defining and maintaining the legitimacy of their CSR practices.

Our results demonstrate that Canada has a clear set of boundaries and parameters that guide the institutional environment. In contrast, in Brazil, these boundaries are not clearly defined and allow for experimentation with new forms of disclosure and approaches to CSR (Abreu et al., 2015). For Brazil, one lesson learned in this research is the need for better governance of the institutional environment to broaden the disclosure of social and environmental practices. At the same time, the financial system has a strong influence on firms and whether they increase the disclosure of their practices. Also, effective 
disclosure requires a better relationship between employees and employers.

We end by highlighting the potential and limitations of CSR disclosure. Brazil can be considered a "land of contradictions" in which society, companies, and government deal with severe deficiencies in the institutional environment. Disclosure of social and environmental practices enables a dialogue in order to include socially responsible actions. This process must recognize the interconnections between the organizational field and the institutional framework and be guided by ethical and moral aspects.

The study has limitations that must be recognized. One limitation involves the short period analyzed, due to the unavailability of institutional indicators to present a long time series, as well as the unavailability of CSR reports. Another limitation is the small number of firms researched. The reduced sample was due to the choice of environmentally sensitive sectors and the decision to obtain a similar number of observations for both countries.

Although there are empirical limitations in the research, the firms and indicators were carefully chosen to represent Brazil and Canada. The study demonstrates the importance of the relationship between CSR disclosure and the institutional environment. It was observed, therefore, that comparative studies in institutionally distant countries, using the proposed econometric model, contribute to understanding the influence of coercive, normative, and cognitive isomorphic pressures on CRS practices.

\section{References}

Abreu, M. C. S., Cunha, L. T., \& Barlow, C. Y. (2015). Institutional dynamics and organizations affecting the adoption of sustainable development in the United Kingdom and Brazil. Business Ethics: A European Review, 24(1), 73-90.

Ali, W., \& Rizwan, M. (2013). Factors influencing corporate social and environmental disclosure (CSED) practices in the developing countries: an institutional theoretical perspective. International Journal of Asian Social Science, v. 3, n. 3, p. 590609, 2013.

Baum, I. \& Oliver, C. (1991). Institutional linkages and organ- izational mortality. Administrative Science Quarterly, 36, 187-218.

Berry, H.; Guillén, M. F. \& Zhou, N. (2010). An institutional approach to cross-national distance, Journal of International Business Studies, 41 (9), 1460-1480.

Bovaird, T., \& Löffler, E. (2003). Evaluating the quality of public governance: indicators, models and methodologies. International Review of Administrative Sciences, 69(3), 313-328.

Brookes, M., Brewster, C., \& Wood, G. (2005). Social relations, firms and society: a study of institutional embeddedness. International Sociology, 20(4), 403-426.

Cheah, E. T., Jamali, D., Johnson, J. E. V., \& Sung M.-C. (2011). Drivers of corporate social responsibility attitudes: the demography of socially responsible investors. British Journal of Management, 22(2), 305-323.

Cheng, B.; Ioannou,I. \& Serafeim, G. (2014). Corporate social responsibility and access to finance. Strategic Management Journal. 35, 1-23.

Chih, H., Chih, H., \& Chen, T. (2010). On the Determinants of Corporate Social Responsibility: International Evidence on the Financial Industry. Journal of Business Ethics, 93(1), 115-135.

Conceição, S. H., Dourado, G. B., Baqueiro, A. G., Freire, S.; Brito, P. C. (2011). Fatores determinantes no disclosure em Responsabilidade social corporativa (RSC): um estudo qualitativo e quantitativo com empresas listadas na Bovespa. Gestão \& Produção, 18, 3, 461-472.

Damiano-Teixeira, K.M. \& Pompermayer, M. M. (2007). Corporate Social Responsibility: Profile 
and Diagnosis of 797 Programs Developed in Brazil, Business and Society Review, 112, 343-367.

Dhaliwal, D., Li, O. Z., Tsang, A., Yang, Y. G. (2014). Corporate social responsibility disclosure and the cost of equity capital: the roles of stakeholder orientation and financial transparency. Journal of Accounting and Public Policy, 33, 328-355.

Debreceny, R., Gray, G., \& Rahman, A. (2002). The determinants of internet financial reporting. Journal of Accounting and Public Policy, 21, 371-394.

Delmas, M. A. (2002). The diffusion of environmental management standards in Europe and in the United States: an institutional perspective. Policy Sciences, 35, 91-119.

DiMaggio, P. J., \& Powell, W. W. (1983). The iron cage revisited: institutional isomorphism and collective rationality in organizational fields. American Sociological Review, 48(2), 147-160.

Dögl, C. \& Behnam, M. (2015). Environmentally sustainable development through stakeholder engagement in developed and emerging countries. Business Strategy and the Environment. 24, 583600.

Fischer, T. M., \& Sawczyn, A. A. (2013). The relationship between corporate social performance and corporate financial performance and the role of innovation: evidence from German listed firms. Journal of Management Control, 24(1), 27-52.

Ghoul, S. E., Guedhami, O. \& Kim Y. (2017). Country-level institutions, firm value, and the role of corporate social responsibility initiatives. Journal of International Business Studies, 48 (3), 360-385.

González-Benito, J. \& González-Benito, O. (2006). A review of determinant factors of environmental proactivity. Business Strategy and the Environment, 15, 87-102.
Haig, M. \&Hazelton, J. (2004). Financial markets: a tool for social responsibility? Journal of Business Ethics, 52. 59-71.

Hybels, R. C. (1995). On legitimacy, legitimation and organi- zations: A critical review and integrative theoretical model. Proceedings on the Academy of Management: 241-245.

Huang, S. K. (2013). The Impact of CEO Characteristics on Corporate Sustainable Development. Corporate Social Responsibility and Environmental Management, 20(4), 234-244.

Ioannou, I, \& Serafeim, G. (2012). What drives corporate social performance? The role of nationlevel institutions. Journal of International Business Studies, 43(9), 834-864.

Jamali, D. \& Karam, C. (2018). Corporate social responsibility in developing countries as an emerging field of study. International Journal of Management Reviews, 20 (1), 32-61.

Kogut, B. (1991). Country capabilities and the permeability of borders. Strategic Management Journal, 12, 33-47.

Kostova, T. \& Zaheer, S. (1999). Organizational legitimacy under conditions of complexity: the case of the multinational enterprise. Academy of Management Review, 24 (1), 64-81.

Lattermann, C., Kupke, S., \& Schneider, A. M. (2007). Corporate social responsibility and the capabilities based view: a case study of a multinational enterprise. Revue de l'Organisation Responsable, 2(3), 18-29.

Li, S., Fetscherin, M., Alon, I., Lattemann, C. \& Yeh, K. (2010). Corporate Social Responsibility in Emerging Markets: The Importance of the Governance Environment

MIR: Management International Review, 50 (5), 635-654

Matten, D., \& Moon, J. (2008). "Implicit" and

“explicit” CSR: a conceptual framework for a 
comparative understanding of corporate social responsibility. Academy of Management Review, 33(2), 404-424.

Murillo-Luna, J.L.; Garcés-Ayerbe, C. RiveraTorres. (2008). Why do patterns of environmental response differ? A stakeholders' pressure approach, Strategic Management Journal, 29, 1225-1240.

Muttakin, M. B.; Khan, A.; Subramaniam, N. (2015). Firm characteristics, board diversity and corporate social responsibility: evidence from Bangladesh. Pacific Accounting Review, 27(3), $353-372$.

Ntim, C.G., Soobaroyen, T. (2013). Corporate governance and performance in socially responsible corporations: New empirical insights from neoinstitutional framework. Corporate Governance: An International Review, 21, 468-494.

Orlitzky, M., Louche, C., Gond, J.-P., \& Chapple, W. (2015). Unpacking the drivers of corporate social performance: a multilevel, multistakeholder, and multimethod analysis. Journal of Business Ethics, 126, 1-20.

Preuss, L., Barkemeyer, R., \& Glavas, A. (2016). Corporate social responsibility in developing country multinationals: identifying company and country-level influences. Business Ethics Quarterly, 26(3), 347-378.

Reed, D. (2002). Employing normative stakeholder theory in developing countries. A critical theory perspective, Business \& Society, 41, 166-207.

Roberts, R. W. (1992). Determinants of corporate social responsibility disclosure: an application of stakeholder theory. Accounting, Organizations and Society, 17(6), 595-612.

Schrammel, T. (2013) Bridging the Institutional Void: An Analytical Concept to Develop Valuable Cluster Services. Management revue, 24 (2), 114-132.
Scherer, A. G. and Pallazo, G. (2008) Globalization and Corporate Social Responsibility, In Crane, A., McWilliams, A., Matten, D., Moon, J. and Siegel, D.S., The Oxford Handbook of Corporate Social Responsibility, Oxford University Press, Oxford, p.413-431.

Economia Aplicada

Sonaglio, C. M, Zamberlan, C. O., Lima, J. E. \& Campos, A. C. (2010). Evidências de desindustrialização no Brasil: uma análise com dados em painel. Economia Aplicada, 14 (4), 347-372.

Tang, L., \& Li, H. (2009). Corporate social responsibility communication of Chinese and global corporations in China. Public Relations Review, 35(3), 199-212.

Thorne, L.; Mahoney, L. S.; Gregory, K. \& Convery, S. (2017) A Comparison of Canadian and U.S. CSR Strategic Alliances, CSR Reporting, and CSR Performance: Insights into Implicit-Explicit CSR. Journal of Business Ethics, 143 (1), 85-98.

Tschopp, D., Wells, S \& Barney, D. (2012). The institutional promotion of corporate social responsibility reporting. The Journal of Academic and Business Ethics, 12, 1-17.

van Der Laan, S. (2009). The role of theory in explaining motivation for corporate social disclosures: voluntary disclosures vs 'solicited' disclosures. Australasian Accounting Business and Finance Journal, 3(4), 15-29.

Visser, W. (2008). Corporate responsibility in developing countries, in Crane, A.; McWilliams, A. Matten, D.; Moon, J.; Siegel, D.S. (Eds). The Oxford Handbook of Corporate Social Responsibility. Oxford University Press, Oxford, pp. 473-499.

Whitley, R. (1999). Divergent Capitalisms: the social structuring and change of business systems. Oxford: Oxford University Press. 
Whitley, R. (2003). How national are business systems? The role of different state types and complementary institutions in constructing homogenous systems of economic coordination and control. Workshop on National Business Systems in the New Global Context, Oslo.

Xu, D. \& Shenkar O. (2002) Institutional Distance And The Multinational Enterprise, Academy of Management Review, 27(4), 608-618.
Yang, X. \& Rivers, C. (2009) Antecedents of CSR practices in MNCs' subsidiaries: A stakeholder and institutional perspective, Journal of Business Ethics, 86,155-169

Young, S. \& Marais, M. (2012). A multi-level perspective of CSR reporting: the implications of national institutions and industry risk characteristics. Corporate Governance: An International Review, 20 (5), 432-450. 


\section{Supporting Agencies:}

National Council for Scientific and Technological Development - CNPq - under Project \# 446047/2014-7

\section{Authors:}

1. Romulo Alves Soares, PhD Candidate, Federal University of Ceará, Fortaleza, Brazil.

E-mail: romulosoares@ufc.br

ORCID

(iD) 0000-0003-2412-3796

2. Mônica Cavalcanti Sá de Abreu, PhD, Business Department, Federal University of Ceará, Fortaleza, Brazil. E-mail: mabreu@ufc.br

ORCID

(iD) 0000-0001-9408-5604

3. Pedro de Barros Leal Pinheiro Marino, Master in Business and Accounting, Business Department, Federal Institute of Brasilia, Brasilia, Brazil.

E-mail: pedroblpmarino@gmail.com

\section{ORCID}

(iD) 0000-0002-6469-8984

4. Silvia Maria Dias Pedro Rebouças, PhD, Business Department, Federal University of Ceará, Fortaleza, Brazil. E-mail: smdpedro@gmail.com

ORCID

(iD) 0000-0002-8475-9748

\section{Contribution of each author}

\begin{tabular}{lccc}
\hline Contribution & $\begin{array}{c}\text { Romulo } \\
\text { Alves }\end{array}$ & $\begin{array}{c}\text { Mônica } \\
\text { Cavalcanti }\end{array}$ & $\begin{array}{c}\text { Pedro } \\
\text { Marino }\end{array}$ \\
$\begin{array}{l}\text { Silvia } \\
\text { Rebouças }\end{array}$ \\
\hline $\begin{array}{l}\text { 1. Definition of research problem } \\
\text { 2. Development of hypotheses or research questions (empirical studies ) }\end{array}$ & $\sqrt{ }$ & $\sqrt{ }$ & $\sqrt{ }$ \\
3. Development of theoretical propositions (theoretical Work) & $\sqrt{ }$ & $\sqrt{ }$ & $\sqrt{ }$ \\
4. Theoretical foundation/Literature review & $\sqrt{ }$ & $\sqrt{ }$ \\
5. Definition of methodological procedures & $\sqrt{ }$ & $\sqrt{ }$ \\
6. Data collection & $\sqrt{ }$ & $\sqrt{ }$ \\
7. Statistical analysis & $\sqrt{ }$ & $\sqrt{ }$ \\
8. Analysis and interpretation of data & & $\sqrt{ }$ \\
9. Critical revision of the manuscript & $\sqrt{ }$ & $\sqrt{ }$ \\
10. Manuscript Writing & & & $\sqrt{ }$ \\
11. Other (please specify which) & & & $\sqrt{ }$ \\
\hline
\end{tabular}

